\title{
Museum og mangfold i norsk kontekst
}

INGEBORg HAUGE** OG HACI AKMAN*

Title: Museums and diversity in the Norwegian context.

Abstract: The article focuses on an exhibition entitled "A Pakistani flat in Norway" at the Norsk Folkemuseum museum of cultural history - an exhibition that is considered a front-runner in the portrayal of cultural diversity in a Norwegian context. The article discusses the visions provided by both international and national authorities for a museum in a culturally diverse society, and relates these visions to the actual exhibition praxis at Norsk Folkemuseum. The discourse about a museum of cultural diversity emphasises the importance of minority groups' opportunities for participating in museum activities at different levels. Text analysis is used to consider the ways in which minorities take part in these processes. Detailed analysis of exhibition texts and texts associated with this particular exhibition on the Norsk Folkemuseum web site indicate an approach to cultural diversity that communicates cultural difference between strictly defined groups. This establishes text-based lines of demarcation for "being different", and the reserves the right to define and interpret the material, and the dialogue principle at the heart of visions of cultural diversity finds only limited expression in actual practice. The museum has tried out new ways of collaborating with informant groups, and has contributed to extending the scope of current praxis for exhibition preparation, but these initiatives alone do not live up to authoritative and accepted visions for inclusive diversity.

Key words: Cultural diversity, cultural heritage, museums, power, text, discourse, museum exhibition.

Både internasjonale organer som UNESCO, EU og Europarådet og norske myndigheter understreker kulturinstitusjoners potensial til å bidra til positiv sameksistens og samspill mellom mennesker med ulik bakgrunn. Artikkelen drøfter disse visjonene opp mot praksis i utstillingen Et pakistansk hjem i Norge på Norsk
Folkemuseum. Utstillingen fungerer som et eksempel på hvordan en nasjonal museumsinstitusjon arbeider med internasjonale og nasjonale myndigheters oppfordringer om en bredere mangfoldsinkludering. Artikkelen undersøker først hvilke disse forventningene er. Deretter spør vi med utgangspunkt i Et pakistansk 
hjem $i$ Norge, hva mangfoldsinkludering kan innebære for museet, hvordan mangfoldet representeres i utstillingen og hvilke strategier som brukes i mangfoldsrepresentasjonen og til slutt hvilke fortellinger som konstrueres om et mangfoldig Norge. ${ }^{1}$

En ny museologi ble først annonsert i 1989 (Vergo 1989), og innledet et paradigmeskifte som blant annet kjennetegnes av en dreining fra å spørre hvordan museer opererer til å spørre hvorfor. Den nye museologien er selvrefleksiv og reiser spørsmål om representasjon, om museets rolle i samfunnet og maktaspekter knyttet til museumsvirksomheten. I mangfoldssammenheng representerer ny museologi en utvidet tenkning rundt museumsinstitusjonens forhold til et stadig mer påfallende kulturelt mangfoldig samfunn preget av globale prosesser som migrasjon og overføring av kulturog idéstrømninger. Museene befinner seg innenfor en ny og mangfoldspreget kontekst som innebærer nytenking omkring nasjon, nasjonal identitet og maktstrukturer.

Flere norske museer har hatt midlertidige utstillinger med kulturelt mangfold i landet som tema. Norsk Folkemuseums utstilling Et pakistansk hjem i Norge er derimot den første permanente utstillingen som representerer kulturelt mangfold i form av nyere innvandring (Norsk Folkemuseums [NFM] hjemmeside). Utstillingen kan derfor sees som et uttrykk for endringsprosessene $\mathrm{i}$ den nye museumstenkingen. For museer som har hatt som sin fremste hensikt å bidra i konstruksjonen av en nasjonal identitet, som Norsk Folkemuseum, kan endringsprosessene på den ene siden forstås som en invasjon av den tradisjonelle museumsvirksomheten, og på den andre siden som del av globaliseringsrosessene. En ny, mangfoldig og globalisert kultursituasjon kan på denne måten utfordre museets tidligere samfunnsroller, samtidig som dagens kunnskapssyn utfordrer det objektive og autoritære kunnskapssynet museet ble til innenfor (Johansen et. al. 2002: 23).

En diskursteoretisk tilnærming med fokus på tekstene knyttet til utstillingen, vil belyse mangfoldsinkludering gjennom ulike prosesser knyttet til makt og deltakelse. Tekstene undersøkes både som et produkt av tanketradisjonene ved museet og som kulturell produksjon. Det vil si at de sees som tegn på bakenforliggende tankesett eller ideologier, men samtidig også som utgangspunkt for konstruksjon av slike ideologier. Begrepene makt og deltakelse skaper en teoretisk ramme for studien. Maktbegrepet er en viktig dimensjon ved relasjonene $\mathrm{i}$ et mangfoldig samfunn. Makt viser her til ideologisk makt, det vil si mulighet til å få gjennomslag for sine praksiser og sin oppfatning av normalitet. I henhold til Foucaults forståelse av makt som både undertrykkende og produktiv, kan diskursive praksiser både bidra til å opprettholde eksisterende maktrelasjoner, og utfordre disse (Winther Jørgensen og Phillips 1999: 23). Museumspolitikk og -praksis kan på den måten både reprodusere eksisterende maktforhold og skape nye maktforhold mellom sosiale grupper gjennom konstruksjon av nye verdensbilder. Tilgangen til denne makten handler om mulighet for deltakelse på ulike nivåer. Goodnow (2008 og 2010) har med utgangspunkt i ulike teorier om deltakelse, utviklet en modell for deltakelse tilpasset museumsinstitusjonen. Modellen opererer med fire ulike trinn for deltakelse. For det første er deltakelse en slags inngangsbillett til institusjonen $\mathrm{i}$ form av fysisk og kostnadsmessig adgang, men også deltakelse i form av representasjon i utstillinger og samlinger. Det andre trinnet, refleksiv deltakelse, handler om intellektuell og kulturell til- 


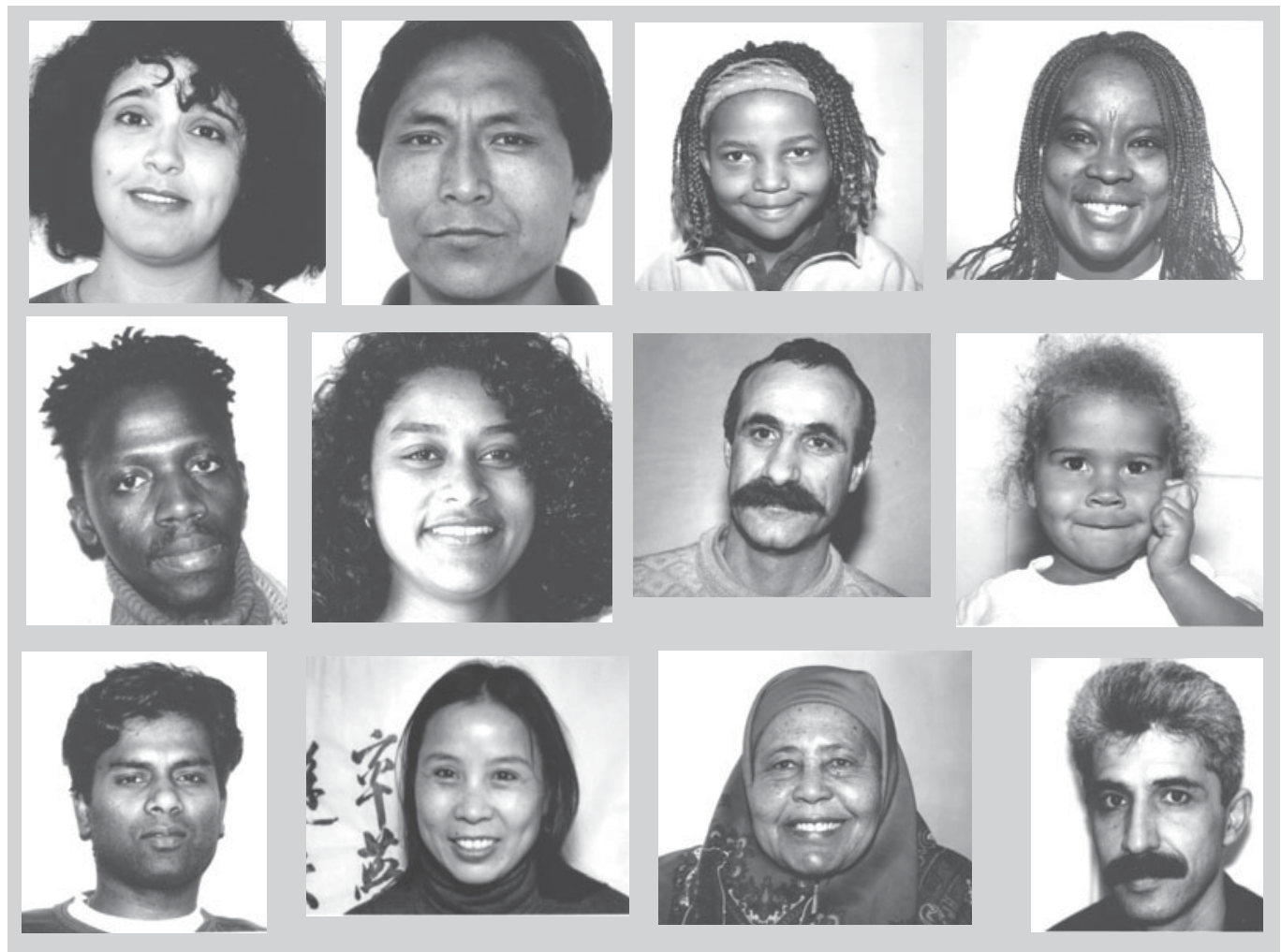

Tittel: "Norges ansikter : en reise i et kulturelt mangfold". Haci Akman. Foto: Yvonne Erdal og Arnfrid Klingsheim Eidesen. Forfatter: Haci Akman. Arstall: 2000. Trykt: Bergen : Forlaget Migrasjonslitteratur. ISBN: 82-993991-49, h. Sidetall: [27] bl. ill. Emner: Etniske grupper | Fotografier. Noter: Katalogisert etter omslag.

gang, det vil si mulighet til å føle tilhørighet til museet og en opplevelse av at kunnskap som formidles er relevant. Trinn tre dreier seg om deltakelse gjennom bidrag, og handler om muligheter for aktiv deltakelse i utforming av utstillinger eller program. Det fjerde trinnet, strukturell deltakelse, vedrører deltakelse i de kuratorielle prosessene, det vil si utformingen av selve budskapet og tolkningen av en utstilling. Strukturell deltakelse handler også om bakenforliggende føringer $\mathrm{i}$ form av standarder for museumsvirksomhet, kompetansekrav og konvensjonell praksis. Makt- og deltakeraspektene handler med andre ord om gruppers tilgang til de ulike delene av museumsinstitusjonens virksomhet.

\section{NORGE, ET MANGFOLDIG SAMFUNN}

Mange samfunn i verden kan betegnes som stadig mer mangfoldige med hensyn til blant annet levemåte, verdisystemer, tradisjoner, ideer, religion og språk. Et slikt mangfold betegnes gjerne som kulturelt mangfold. Mot 
28 slutten av 1980-tallet ble Norge, etter om lag 20 år med innvandring fra land i sør, oppfattet som et kulturelt mangfoldig samfunn av offentligheten (Kjeldstadli 2003: 196). I lys av denne anerkjennelsen begynner en å kalle innvandrere for etniske minoriteter og beskrive samfunnet som et flerkulturelt samfunn. Det siste tiåret har sistnevnte begrep delvis blitt erstattet av kulturelt mangfold eller mangfoldig samfunn. Denne dreiningen framhever viktigheten av relasjonene mellom minoritet og majoritet i samfunnet som helhet og fokuset er i mindre grad alene rettet mot minoritetsgrupper. Mangfoldsåret 2008 i Norge er et konkret eksempel på denne fokusendringen.

Det kulturelle mangfoldet i Norge kan på den ene siden tallfestes. I Norge bor det over 552000 personer som enten har innvandret selv eller er født i Norge med innvandrerforeldre. Til sammen utgjør disse gruppene 11,4 prosent av befolkningen. De har bakgrunn fra 216 ulike land og selvstyrte regioner og har kommet hit som flyktninger, som arbeidsinnvandrere, for å ta utdanning eller gjennom familierelasjoner til noen i Norge. Etter at det ble stopp for arbeidsinnvandring i 1975, har antall flyktninger fra land i Asia, Afrika, Latin-Amerika og Europa utenom EU/EØS økt. Med EU-utvidelsen i 2004 har det skjedd en markant økning i innvandringen fra nye EUland, som Polen og de baltiske statene (Statistisk Sentralbyrå).

I offentlige dokumenter brukes kulturelt mangfold likevel i stadig mindre grad utelukkende om kvantitative forhold. Begrepet forstås mer kvalitativt og normativt og gjerne med en politisk hensikt, nemlig "å utvikle et reelt flerkulturelt samfunn hvor kulturuttrykk møtes og utvikles, og nye kulturuttrykk skapes" (St. mld. 17: 8). Siktemålet er å skape "et samfunn som fører en politikk som har fler- kultur som mål” (St. mld. 48: 31). I henhold til denne forståelsen kan samfunnet være kulturelt mangfoldig i kvantitativ forstand, men likevel ikke reelt sett være kulturelt mangfoldig på grunn av kvalitative mangler. Et samfunn der kulturuttrykk møtes og utvikles, og nye kulturuttrykk skapes forutsetter ikke bare et visst antall mennesker med ulik bakgrunn, men også samhandlinger mellom disse menneskene og konsekvenser av dem. Det handler om ulike gruppers mulighet for deltakelse, innflytelse, anerkjennelse og definisjonsmakt. Politiske institusjoner formulerer med andre ord sosiale mål for samfunnsutviklingen der en såkalt mangfoldspolitikk skal henvende seg til alle borgere i samfunnet og sørge for at fellesstrukturer ikke favoriserer noen grupper og ekskluderer andre. Kulturfeltet anses som et viktig redskap i prosessen mot et velfungerende mangfoldig samfunn.

\section{Museets ROLLE I DET MANGFOLDIGE SAMFUNNET}

Hvilke roller kan museer med sin kompetanse på kulturarvsforvaltning spille i denne utviklingen? Museet, som en viktig del av kulturfeltet, ventes å stimulere til og legge til rette for kulturelt mangfold. Museet forstås i internasjonale og nasjonale offentlige dokumenter, ${ }^{2}$ som en aktiv kulturpolitisk institusjon som for det første skal bidra til positive endringer $i$ samfunnet i form av inkludering og toleranse, men som også skal være arena for debatt, identitetskonstruksjoner og respekt for mangfold. Både $\mathrm{i}$ en internasjonal og en nasjonal mangfoldsdiskurs forventes konkrete endringer i form av åpnere kategorier og mangfold i tilnærminger til temaer, til publikum og til tolkninger. Det anbefales videre at formidlingsstrategiene mangfoldiggjøres for at muse- 
ene skal kunne virke som inkluderende møteplasser. Museene forventes også å legge til rette for at minoriteter, spesielt ikke-vestlige innvandrere selv skal kunne forme og oppleve kulturelle trekk som vedrører egen identitet, samt å sørge for at majoritetsbefolkningen får kunnskap om minoritetene. I denne diskursen om mangfoldsmuseet forstås kulturarv i stor grad som et redskap til å nå sosiale og politiske mål og en kan dermed definere kulturarv som den delen av fortiden som vi velger ut for å tjene formål i nåtiden (Ashworth et. al. 2007: 34). Offentlighetens forventinger til museet som kulturarvsforvalter i et mangfoldig samfunn, må på denne bakgrunnen forstås i lys av politiske modeller for mangfoldige samfunn.

I boka Pluralising Pasts (Ashworth et. al. 2007) opereres det med fem modeller for kulturelt mangfoldige samfunn, der kulturarven fyller ulike funksjoner. Assimilasjonsmodellen beskriver samfunn med ett sett av kjerneverdier og-normer som i liten grad endrer seg til tross for økende mangfold. Minoriteter forventes å fungere innenfor den majoritetsdefinerte kjernen og avvik fra kjernen aksepteres i ulik grad fra passiv aksept til aktivt å hindre dem i å komme til uttrykk. Kulturarvens rolle er å assimilere minoriteter inn i majoritetskulturen (ibid.: 91ff). Melting pot-modellen er en metafor for at ulike grupper smelter sammen til en ny enhetlig kjernekultur. Her endrer altså kjernen seg til en ny, men i likhet med den førstnevnte, fungerer kulturarven også her som redskap til å sosialisere de ulike befolkningsgruppene inn i en felles kulturforståelse (ibid.: 117ff). Søylemodellen består derimot av flere kjerner som er bundet sammen av kollektive forpliktelser til den overordnede superstrukturen. Modellen forutsetter ikke nødvendigvis sosial interaksjon mellom de ulike søylene, kun anerkjennelse av hverandres rett til eksistens. Hver gruppe kan utvikle og forvalte egne kulturelle, sosiale, politiske og økonomiske institusjoner. Den felles statlige kulturarvspolitikken er gjerne svært generell og åpner for regional og lokal kulturarvsforvaltning (ibid.: 164ff). De tre nevnte modellene er i mindre grad relevante for norsk kulturarvspolitikk i dag, men det kan være nyttig å se dagens situasjon tilknytning til disse. Spesielt har assimilasjonsmodellen vært betegnende for tidligere kulturarvspolitikk i landet.

Mer relevante i dag er likevel for det første core+-modeller som beskriver samfunn som har en allerede eksisterende kjerne som definerer de grunnleggende verdiene i samfunnet. Til denne kjernen kan tilføyelser, eller såkalte add-ons legges til. Disse tilføyelsene kan ses som bidrag til eller forsterkninger av kjernen og de kan fungere som underkategorier av kjernen, regionale varianter eller mer eller mindre eksotiske dekorasjoner som kan legges til kjernen når det passer seg (ibid.: 141). Core+-modeller er funnet i vestlige demokratiske samfunn med avklarte nasjonale enheter, men også i postkoloniale samfunn som befinner seg i en nasjonliseringsprosess. Kulturarven kan også her fungere som pådriver for vedlikeholde og promotere verdier i kjernekulturen, men nye bidrag kan inviteres inn $\mathrm{i}$ kjernen om de anses som ikke-truende. Vi kommer tilbake til core+-modellen når utstillingspraksis skal undersøkes gjennom Et pakistansk hjem i Norge.

For det andre er salatbollemodellen aktuell. Den beskriver et samfunn der ulike ingredienser er satt sammen til en helhet uten at delene mister sine særtrekk. En skiller gjerne mellom en deskriptiv og en preskriptiv modell der førstnevnte anerkjenner at samfunnet er mangfoldig, mens den andre fører en bevisst mangfoldspolitikk som tar hensyn til, styrker og 
30 fremhever det mangfoldige samfunn (ibid.: 85). Selv om meningsmangfoldet er stort innenfor denne modellen, kan en si at mangfold anses som en ressurs som bør være universelt tilgjengelig og at kulturarven kan spille en rolle ved å skape arenaer for og å gjøre mangfoldet synlig og tilgjengelig (ibid.: 180ff). Salatbollemodellen rommer også kulturarvspolitikk som søker å bevare integriteten og autentisiteten til de ulike gruppene gjennom å framheve deres særegenheter. Internasjonal og nasjonal kulturarvspolitikk kan fortrinnsvis plasseres innenfor salatbollemodellen. Visjonene, både i form av aksept for mangfold og mulighet til anerkjennelse for egne kulturelle særtrekk, ligger tett opp til hvordan en tenker seg at et mangfoldig samfunn kan fungere innenfor saltbollemodellen.

Vi har nå fătt et visst omriss av hva internasjonale og nasjonale myndigheter forventer av en museumsinstitusjon i et mangfoldig samfunn. Diskursen om et såkalt mangfoldsmuseum representerer myndighetenes visjoner. $\mathrm{Vi}$ skal nå gå over til å se på den reelle praksis ved ett av museene som har tatt mangfoldet på alvor.

\section{ET PAKISTANSK HJEM I NORGE}

Norsk Folkemuseum er landets største kulturhistoriske museum, grunnlagt i 1894. Det rommer både et friluftsmuseum og faste og temporære utstillinger. I januar 1999 ble en tre etasjes leiegård i Wessels gate 15 i Oslo revet for å gjenoppbygges på Norsk Folkemuseums byavdeling. Leilighetsgården ruver i dag over små trehus og skigarder på friluftmuseets område. Formålet med bygården, den såkalte OBOS-gården, er å vise boskikk og hjemidealer i Oslo i ulike tidsepoker i gårdens levetid fra 18651999 (NFM hjemmeside). Den består av i alt åtte leiligheter, blant annet Et pakistansk hjem $i$ Norge.

Utstillingstekster er en forholdsvis betydelig del av utstillingene i OBOS-gården. De meddeler for det første hvilke omstendigheter museet ønsker å rette oppmerksomhet mot og hvilken kontekst de ønsker å plassere utstillingene i, men også hvilke normer eller diskurser som ligger bak den virksomheten som drives. Tekstene kan derfor være en hensiktsmessig innfallsvinkel til hva mangfoldsinkludering kan innebære for museet, hvordan mangfoldet representeres i utstillingen og hvilke strategier som brukes i mangfoldsrepresentasjonen. Utgangspunkt for analysen er utstillingstekstene og presentasjon av utstillingen på museets hjemmeside.

\section{OBOS-GÅRDEN SETT UNDER ETT}

På informasjonsplakaten i hovedinngangen til bygården presenteres de åtte leilighetene i kronologisk rekkefølge under overskriften Bolighistoriske innredninger. Den eldste leiligheten er Et dukkehjem fra 1879 og den nyeste er Et pakistansk hjem i Norge fra 2002. Her er leilighetene først og fremst representasjoner av innredninger fra bestemte tidsrom. Et pakistansk hjem $i$ Norge fungerer i denne sammenhengen ikke først og fremst som en representasjon av en minoritetsgruppe i Norge, men snarere som en representasjon av innredningsstiler. Dette kan sees som en mangfoldsstrategi der forskjellskommuniseringen er nedtonet og utstillingen kan forstås som en bestrebelse mot å vise mangfold snarere enn et ønske om å vise en representativ innredningsstil i Norge i 2002.

OBOS-gården forteller som helhet blant annet om klasseforskjeller og nasjonalfølelse i 1905, om sosialdemokrati og modernisering i 
1960 og om etnisk mangfold i 2002 og kan leses som et manifest på mangfold i tid, etnisitet, stil, politisk interesse, klasse og yrke. Både $\mathrm{i}$ introduksjonen på hjemmesiden og på informasjonsplakaten opererer museet med et utvidet mangfoldsbegrep der etnisk mangfold er ett aspekt i mangfoldsbegrepet.

\section{TEKSTENE KNYTTET TIL ET PAKISTANSK HJEM I NORGE}

Utstillingstekstene i gangen i Et pakistansk hjem $i$ Norge gir en introduksjon til utstillingen. De forteller blant annet at det er ramadan, at noen av tingene i leiligheten er kjøpt i Norge og andre i Pakistan, at pakistanere kom til Norge fra 1960-tallet og i dag teller ca 20.000. På vei inn i utstillingen leser vi: "På gulvene ligger tepper, og vi ber deg ta av deg skoene eller ta på overtrekkssokker før du går videre innover". Når en setter skoene fra seg ved inngangsdøra og går inn i stua, kan det oppleves som å være på vei inn på besøk til noen. Sola lyser opp plastblomstene $\mathrm{i}$ vinduskarmen og fra TV sørger vakre indiske dansere i en Bollywood-film for bakgrunnsmusikk. På det ene soverommet er dobbeltsenga pent oppredd med et silkeaktig sengeteppe. Pleksiglasset i døråpningen sørger for at en må iaktta rommet fra døråpningen. På det andre soverommet vitner både kremer, parfymeflasker og en hjertepute fra IKEA om at dette er et ungdomsrom. Datamaskinen ser også ut til å være et viktig inventar. På kjøkkenet står maten klar på serveringsfat.

Tekstene knyttet til utstillingen skal i det videre undersøkes mer inngående ved hjelp av diskursteoretisk tekstanalysemetode (Fairclough 2001 og 2007) og innenfor rammene av Goodnows (2008 og 2010) deltakelsesmodell. Deltakelsesmodellen omfatter fire nivåer; deltakelse som inngangsbillett, refleksiv deltakelse, deltakelse som bidrag og strukturell deltakelse. Her fokuserer vi spesielt på nivå to og fire.

\section{DELTAKELSE SOM INNGANGBILLETT TIL MUSEUMSINSTITUSJONEN}

Det første nivået i modellen handler om ulike gruppers konkrete adgang til museet. I utvidet forstand kan adgangen omfatte gruppers representasjon blant publikum, i utstillingene og i samlingene. Om vi ser pakistanere som representanter for minoriteter i Norge, har Norsk Folkemuseum gjennom utstillingen $E t$ pakistansk hjem i Norge gitt adgang til nye minoritetsgrupper både i utstillinger og samlinger. Pakistaneres kulturelle uttrykk har gjennom utstillingen fătt en permanent plass ved museet og blitt en del av institusjonens samlinger.

Inkluderingen av Et pakistansk hjem i Norge signaliserer at pakistanere er en ansett og viktig del av norsk kulturarv. Publikummere som identifiserer seg med noe i den pakistanske leiligheten får dermed bekreftet sin plass i det norske samfunnet. Det kan hevdes at Norsk Folkemuseum har spesielle muligheter til integrering nettopp på grunn av den faste forankringen museet og museets navn har til det geografiske stedet Norge. Museet har tradisjoner for å definere det kjente og nære og har dermed en gylden mulighet til å fange nye grupper inn under denne kategorien. Gjenkjennelse av særtrekk fra egen kultur ved en så betydelig institusjon, kan ha en anerkjennende betydning for minoritetsgruppene. I institusjonell kontekst har derfor Norsk Folkemuseum en gunstig mulighet til å utvide meningsinnholdet i kategorien det kjenteog nare til også å gjelde mennesker med bakgrunn utenfor Norge. 
32 REFLEKSIV DELTAKELSE; INKLUDERING GJENNOM TEKST

Det andre trinnet, refleksiv deltakelse, handler om intellektuell og kulturell tilgang, det vil si mulighet for nye publikumsgrupper til å føle tilhørighet til museet og en opplevelse av at kunnskap som formidles ved museet er relevant for dem. En utvidet deltakelsesprofil på dette trinnet innebærer tilrettelegging for og tilpasning til nye publikumsgrupper (Goodnow 2010: 123ff).

Analyse av tekstlige konstruksjoner som synonymer, antonymer og subjektposisjoner kan antyde museets underliggende oppfatninger av samfunn og samfunnsgrupper. Tekstene kan gi et bilde av hvorvidt det er tatt høyde for refleksiv deltakelse for nye publikumsgrupper.

I utstillingstekstene og på museets hjemmeside betegnes den pakistanske leiligheten blant annet som; innvandrerleilighet, et pakistansk hjem fra Oslos østkant, museets innvandrerbjem og vare dagers muslimske hjem. Her brukes begrepene innvandrer, pakistansk og muslimsk som tekstuelle synonymer (Fairclough 2001: 80). Det vil si at begrepene brukes til å referere til ett og samme fenomen; det pakistanske hjemmet, men at de ikke nødvendigvis er synonymer når det gjelder meningsinnhold.

Utstillingsteksen som omhandler dobbeltsengen, knytter den til innvandreres smak, ikke til pakistaneres: "[D]enne modellen selges nesten utelukkende til innvandrere". Museumsansatte forklarer at dobbeltsengen i utstillingen ble valgt ut fra en opplysning museet fikk om at "alle pakistanere i Oslo ønsker seg en slik seng" (Pareli 2004). Som i eksempelet overfor, viser begrepene innvandrer og pakistaner til det samme fenomenet, men innvandrer brukes som markør for meningsinnholdet i pakistaner i Norge.
Begrepene er med andre ord ikke brukt konsekvent til å vise til et bestemt meningsinnhold og grensene mellom begrepene er diffuse og varierende. Utstillingen fremstår gjennom tekstene som en representasjon av en gruppe mennesker som kan karakteriseres med de tre begrepene muslim, pakistaner og innvandrer, en svært omfattende og heterogen gruppe. Tekstene skaper relasjoner mellom de tre begrepene, noe som fører til at tilhørighet til den ene kategorien forutsetter tilhørighet til de andre. En muslim er underforstått også innvandrer og pakistaner og vice versa. Det konstrueres med andre ord en gruppe som deler bestemte grunnleggende egenskaper og mangfoldet innad i denne store kategorien er usynliggjort gjennom anvendelsen av de tre begrepene som synonymer.

Gruppen som konstrueres, står i tekstene i relasjon til andre grupper. En analyse av begrepsmessige motsetninger, det vil si antonymer, kan kaste lys på denne gruppens relasjon til andre grupper. Antonymer viser til en konseptuel todeling som organiserer fenomener i adskilte kategorier. Her forstås antonymer som praktisk funderte dikotomier som ikke nødvendigvis utelukker hverandre prinsipielt og logisk, men som er resultat av de historiske sammenhengene de oppstår i (Miegel og Schough 1998: 14). Dette innebærer at dikotomiene forstås som menneskeskapte kategoriseringer heller enn avspeilinger av objektenes iboende natur. Museet har sådan mulighet til å opprettholde eller skape nye dikotomier.

På museets hjemmeside kan vi lese hvordan hjemmet til en pakistansk familie kontrasteres med et norsk hjem. Teksten skaper en dikotomi mellom minoritet og majoritet i det norske samfunnet: "Hvordan ser det så ut hjemme hos en pakistansk innvandrerfamilie, og hva er forskjellig fra et vanlig norsk hjem?”. Denne 
dikotomien etableres også i beskrivelsen av religiøs praksis.

Så å si alle pakistanere er muslimer, og legger vekt på å overholde mange av religionens påbud. Dette står i kontrast til det norske storsamfunnet, der religion for de fleste er perifer eller uinteressant (NFM hjemmeside).

Museet kontrasterer de angivelige pakistanske og norske religiøse skikkene. Både majoritetsbefolkningen og pakistanske muslimer blir plassert i lukkede kategorier med bestemte kjennetegn; en er enten opptatt av å overholde religiøse påbud, eller en forstår religion som noe perifert og uinteressant. Teksten åpner ikke for at en kan være både norsk og muslim eller pakistaner med liten interesse for religion. Dikotomiseringen umuliggjør parallelle posisjoner og den ene kategoriens meningsinnhold er inkompatibelt med den andre. En slik dikotomisering kan være et hinder for stimuleringen til og tilretteleggingen for kulturelt mangfold $\mathrm{i}$ form av åpnere kategorier og mangfold i tilnærminger til temaer, til publikum og til tolkninger.

\section{TEKSTENES HENVENDELSE TIL EN IDEELL LESER}

Avstand mellom produsent og tolker er karakteristisk for mediatekster. Også i museer skriver tekstprodusenten for et massepublikum som han eller hun ikke har noe nært forhold til. Tekstprodusenten forestiller seg en ideell leser med bestemte erfaringer og meninger som teksten relateres til (Fairclough 2001: 41). Dette innebærer tanker om hvordan leseren vil oppfatte budskapet. I utstillingstekstene handler dette om hvilken informasjon museet mener leseren trenger for at teksten skal være meningsfull. I disse antakelsene finner en forsestillingene om hvem publikum er.

Forestillingene om en ideell leser kan belyses med den tidligere anvendte setningen: "Hvordan ser det så ut hjemme hos en pakistansk innvandrerfamilie, og hva er forskjellig fra et vanlig norsk hjem?" (NFM hjemmeside). Her oppfordres leseren til å sammenligne et norsk hjem og et innvandrerhjem. Museet antar at leseren har erfaringer med et vanlig norsk hjem og at pakistanske leiligheter representerer noe ukjent. En majoritetsnorsk leser vil formodentlig passe inn i denne antakelsen, mens en leser som mangler erfaringer med vanlige norske hjem, men kjenner pakistanske leiligheter, ikke samsvarer med tekstens forventinger til leseren. Her er med andre ord refleksiv deltakelse forbeholdt publikum med erfaringer med majoritetsnorske hjem.

Majoritetens rolle som publikum utdypes videre:

Også nordmenns smak varierer, som vi alle vet, og mens en funkisorientert tilskuer kanskje vil betegne innvandrerleiligheten som overlesset, vil den plysj- og prismeorienterte trolig føle seg mer hjemme i pakistanerens dype velursofa enn i stålrørsstolen hos en norsk minimalist (NFM hjemmeside).

I dette utdraget skaper teksten en relasjon mellom publikum og museet gjennom innskytelsen, "som vi alle vet". Museet henviser til et $v i$ som tar det som en selvfølge at nordmenns smak varierer. Museet selv befinner seg innenfor denne gruppen sammen med andre som deler denne erkjennelsen. $\AA$ kunne ta mye for gitt er et viktig tegn på å høre til i en gruppe. Gruppeidentiteter bygger på en felles oppfatning av hva som er innlysende og naturlig eller hva som er common sense (Fairclough 2001: 77f). Kollektive common sense- 
34 antakelser kan etablere solidaritetsforhold mellom medlemmer $i$ en gruppe og gjennom å fremstille nordmenns smaksvariasjon som common sense, framstilles erkjennelsen som udiskutabel og selvfølgelig. Kunnskap om at norske stiler varierer er selvfølgeliggjort, mens ulike pakistanske stiler ikke nevnes. Dette bidrar til å skape et oss med felles referanserammer og et mangfold av stiler og et $d e$ med andre erfaringer uten mangfold innad.

Forhåndskunnskapene og -erfaringene som kreves for at teksten i dette eksempelet skal være relevant, korresponderer i stor grad med majoritetens erfaringer. Når leserens erfaringer og kunnskap avviker fra den ideelle leseren, ekskluderes hun eller han fra deltakelse i en felles meningskontekst. Teksten skaper et eksklusivt fellesskap mellom tekstforfatter eller museet og de blant publikum som deler deres erfaringer.

\section{SELVTILSKREVET OG TILSKREVET IDENTITET I TEKSTENE}

Identitet er et framtredende begrep i mangfoldssammenheng og viser til en følelse av å være unik samtidig som det er en opplevelse av tilhørighet til en gruppe. Identitet har på den måten en relasjonell dimensjon. Det handler om hvordan en definerer seg selv; selvtilskrevet identitet, og hvordan en blir definert og forstått av andre; tilskrevet identitet (Akman 1995: 48). Tilskrevet og selvtilskrevet identitet kan komme i konflikt. Majoritet og minoriteter tilbys gjennom tekstene ulike identiteter eller subjektposisjoner (Winther Jørgensen og Philips 1999: 57f). Tekstanalyser kan peke på i hvor stor grad disse rollene er åpner for aktive og passive subjekter og for selvtilskrevet og tilskrevet identitet.

I sitatet over er majoriteten betegnet som nordmann og minoriteten representert gjennom begrepet pakistaner. Innenfor disse kategoriene tilbys majoriteten en ekspertrolle som gjør at de kan definere og vurdere den pakistanske leiligheten som overlesset eller hjemmekoselig. Normen for hva som er fint bestemmes av en annen gruppe enn den gruppen som representeres og leiligheten kan sies å bli tilskrevet en identitet av de norske ekspertene. Teksten åpner ikke for en selvtilskrevet karakteristikk av den pakistanske leilighetens stil. Majoritet og minoriteter deltar dermed ikke på de samme premissene.

I det samme sitatet tilbys nordmenn videre rollen som funkisorienterte, plysj- og prismeorienterte og minimalister, mens pakistanerne kun tilbys rollen som innvandrere. Majoritetens subjektposisjoner er sammensatte og nyanserte, mens pakistanere er låst til en kategori. Stilen i pakistanske hjem er i motsetning til nordmenns, knyttet til nasjonalitet.

Pakistaneres subjektposisjon begrenses til å være passivt betraktede uten mulighet til selvtilskrevet identifikasjon, mens majoritetsbefolkningen tildeles en posisjon som eksperter, får en aktiv rolle i interaksjonen og gis mulighet til å aktivt beskrive og vurdere utstillingen. Eksempelet viser hvordan minoriteter tekstlig kan ekskluderes fra refleksiv deltakelse.

\section{DELTAKELSE SOM BIDRAG}

Nivå tre, deltakelse gjennom bidrag, handler om innflytelse i utformingsprosessen og planleggingen av utstillinger. Museet har gjort en rekke grep for å imøtekomme visjonen om deltakelse for minoriteter og gjøre pakistanere til aktive deltakere i utformingen av utstillingen. En pakistansk informantfamilie har blitt brukt som ressurspersoner, nettverksåpnere og konsulenter i utformingen av Et pakistansk 
hjem i Norge. De har vært med å velge møbler, pyntegjenstander, bilder og organisere interiøret i de ulike rommene. Slik har museet sørget for at det tilrettelegges for minoriteters deltakelse i utstillingens utforming. Pakistanere er blitt anerkjent som en del av fellesskapet og museet skaper gjensidig integrasjon mellom museet og minoriteten gjennom nye forståelsesrammer for museumspraksis. Det tette samarbeidet mellom museet og informantfamilien har sørget for en høy grad av selvrepresentasjon i selve utstillingen. Utstillingstekstene er derimot ikke et produkt av et slikt tett samarbeid. Her er det først og fremst museets stemme som taler. Pakistanere har kun hatt en konsulær rolle i den overordnede tekstlige utformingen av utstillingen. Museet konsulterte pakistanere etter at tekstene var skrevet og gjorde endringer som pakistanerne anbefalte, men de var ikke med på å definere hvilke punkter som var viktige i formidlingen av leiligheten og hvilke tilnærmingsmåter en skulle bruke. Pakistanernes deltakelse i disse meningsskapende prosessene har dermed vært begrensede.

Såkalt partial participation er en prosess der to eller flere grupper påvirker hverandre i avgjørelser, men der makten til å ta den endelige avgjørelsen ligger hos en av gruppene (Goodnow 2010: XXV), i dette tilfellet museet. Det er for eksempel museet som har bestemt innholdet i tekstene og dermed bestemt hvilken tolkningskontekst utstillingen skal plasseres inn i. Denne praksisen kan sies å falle inn under core+ modellens mangfoldsstrategier i og med at bidrag ønskes velkommen så lenge det ikke rokker ved kjerneverdiene i majoritetssamfunnet.

\section{STRUKTURELL DELTAKELSE}

Trinn fire i deltakelsesmodellen, strukturell del- takelse, dreier seg om virksomhetens bakenforliggende hindringer og muligheter for innflytelse i diskursen. Utdanning, ansettelser, sjanger og innarbeidede praksiser kan legge bestemte føringer på virksomheten og være så naturalisert, at det ikke forstås som resultat av et valg og heller ikke trenger begrunnelse. På denne bakgrunnen er strukturell deltakelse direkte knyttet til ideologisk makt. Siste del av artikkelen vil vies refleksjoner rundt strukturell deltakelse i form av ideologisk makt som kommer til uttrykk gjennom museumsutstillinger som sjanger.

\section{IDEOLOGISK MAKT OG COMMON SENSE}

Ideologisk makt handler som sagt om muligheten til å definere praksiser og gi mening til begreper og kategorier som konstituerer vår oppfatning av verden, eller å være i en posisjon som gjør det mulig å være med å definere common sense (Fairclough 2001: 77f). Når praksiser eller oppfatninger er blitt common sense, vil det si at disse er så normalisert og inneforstått at de som er fortrolige med dem ikke har behov for nærmere begrunnelse eller forklaring. Common sense-oppfatninger og - praksiser skaper på den måten hegemoniske diskurser der de underliggende premissene for praksis kan bli usynlige for aktørene. Om vi antar at det finnes common sense-oppfatninger om hvordan virksomheten $\mathrm{i}$ et $\mathrm{mu}$ seum skal foregå, kan mangfoldsdiskursen representere en utfordring av disse på flere plan. Museer kan bidra i samfunnets meningsdannelser og prosess mot et velfungerende mangfoldig samfunn, blant annet gjennom å redefinere sammenhenger og praksiser som naturlige, selvsagte og universelle skape nye meningsinnhold i begreper og kategorier. Vi skal se på hvordan sjanger kan legge bestemte fø- 
36 ringer for interaksjon, maktfordeling og mening.

\section{UTSTILLINGSSJANGRE I MUSEER}

Museumsutstillinger har tradisjonelt operert med en sender-mottaker form for kommunikasjon der museet har sendt et budskap til publikum gjennom utstillingen, og der publikum har vært passive mottakere av budskapet. Museet har innenfor denne modellen hatt en betydelig strukturell makt i form av tolkningsog definisjonsmakt. Denne formen for interaksjon legger begrensninger for publikums muligheter for deltakelse i tolkningsprosessen av utstillingene og sjangerføringene gir museet råderett over tolkningene. Om vi forstår utstillinger som rammer for handlinger der mennesker interagerer med museet og med selve utstillingen, er det hensiktsmessig å se utstillingssjangre som et resultat av makt og ideologisk kamp. Utstillingspraksis kan ha blitt så innarbeidet at de "ikke trenger noen normativ begrunnelse for å være handlingsstyrende" (Tvedt 1999: 120). I diskursen om mangfoldsmuseet uttrykkes derimot et ønske om at museet skal være møteplass for et mangfold av meningsutvekslinger, tolkninger og praksiser. Disse forespeilte endringen rommer en demokratisering av den strukturelle deltakermakten og utfordrer monologformen.

Museumsutstillinger kan deles i ulike underkategorier. Naguib (2004) og Goodnow (2008) drøfter ulike utstillingstyper ved kulturhistoriske museer. Naguib ser utstillingene i et historisk perspektiv, mens Goodnow diskuterer nåtidige og framtidige utstillingstyper.

Naguib skiller mellom tematiske utstillinger som skaper en stor fortelling om nasjonal enhet, og kontekstuelle utstillinger som knyttes til mange små fortellinger om nasjonens mang- foldige innbyggere. Dagens utstillinger befinner seg $\mathrm{i}$ en mellomstilling mellom disse mener hun. Kulturhistoriske museer er fremdeles kulturelle ikoner for nasjonalstaten, symbol på en idealisert, homogen nasjon og en autoritativ utdanningsinstitusjon for befolkningen. Samtidig fungerer museet også som en kontaktsone og dialog for eksperiment, debatt og konfrontasjon som utfordrer klassifiseringer som oss og de andre (Naguib 2004: 7)

Tematiske utstillinger ble vanlige fra 1930tallet. Modeller ble kledd i "autentiske" kostymer og "autentiske" situasjoner ble rekonstruert. Kontekst og hensikt var gjerne fraværende og den vanligste tilnærmingsmåten var å understreke annerledeshet i negasjon til det kjente. Hvor og når ble fremhevet snarere enn hvorfor og hvordan. Dette førte til stereotypisering og en forestilling om primitive kulturer urørt av moderne tider (Ibid.: 10). I likhet med tematiske utstillinger er den Et pakistansk hjem $i$ Norge utformet med et tydelig ønske om å skape en autentisk situasjon som er i overensstemmelse med en virkelig leilighet der det bor en pakistansk familie. I form ligner utstillingen på dioramaer der den fjerde veggen i rommet erstattes med et pleksiglass som gir publikum mulighet til innsyn. Glassveggen markerer grensen mellom publikums verden og den verden som betraktes og tydeliggjør forskjellene mellom en verden bak og en verden foran glasset. En pakistansk leilighet i Norge kan likevel på ingen måte likestilles med tematiske utstillingstyper. For det første er hensikten bak inkluderingen et ønske om å vise mangfold med en inkluderingshensikt. For det andre er utstillingen ikke utelukkende konstruert av museumspersonellet. Den pakistanske informantfamilien har i stor grad vært delaktige i utformingen av leiligheten. innhold kan utstillingen likevel ikke sammenlignes med tematiske utstillinger. 
Fra 1990-årene ble tematiske utstillinger kritisert, spesielt av minoriteter og urfolk som begynte å danne egne museer for å presentere sine versjoner av historien. Dette tvang kulturhistoriske museer til å anvende varierte innfallsvinkler i utstillingene og til å gi minoriteter en stemme. Kontekstuelle, interaktive utstillinger tok delvis over for de tematiske utstillingene. I den nye diskursen anerkjenner museene at kunnskap er konstruert, de har et tolkende og analytisk rammeverk og metodene viser publikum at presentasjonen er bestemt av tid og sted. Mindre fortellinger fortalt fra ulike vinkler, erstatter Den Store Fortellingen og en ser tendens til flere mindre temporære utstillinger i stedet for store permanente (ibid.: 9). Det konstruktivistiske postmoderne vitenskapssynet i de kontekstuelle utstillingene samsvarer med mangfoldsmuseets ideologi.

I sin beskrivelse av samtidens utstillinger, mener Goodnow at utstillingstypen hun kaller enhancement narratives er dominerende. Hun plasserer Et pakistansk hjem i Norge innenfor denne utstillingssjangeren (Goodnow 2008: 234). Enhancement narratives deler visse karakteristikker med tematiske utstillinger. Utstillingene fremstiller majoriteten i landet som veletablert og homogen. En snakker for eksempel om den norske kulturen til tross for mangfold også i fortiden. Videre fremheves minoriteters annerledeshet og hva disse gruppene kan tilføye landet, gjerne i form av mat, musikk og håndverk. På denne måten samsvarer utstillingssjangeren med den tidligere nevnte core+-modellen for mangfoldige samfunn. Likheten med de tematiske utstillingene ligger først og fremst i fokuset på annerledeshet og essensialiseringen av grupper. Den viktigste forskjellen handler om at formålet med å understreke annerledeshet er å promotere respekt for mangfold og at holdningen til mang- fold er positiv. Representanter for enhance-

ment narratives vil hevde at utstillinger av kulturell ulikhet kan brukes for å redusere rasisme og øke toleranse (ibid.: 233). Utstillingstypen muliggjør en positiv selvidentifikasjon, men risikerer å stenge mennesker inne i statiske kategorier der essensialisme overskygger sosial og økonomisk hybriditet og fleksibilitet. Migranter har tendens til å bli folklorisert og essensialisert. I tekstene knyttet til Et pakistansk hjem i Norge hører vi i motsetning til de andre leilighetene i OBOS-gården, verken om navn, yrke, utdannelse, klasse eller alder. Interiør og stil forklares med at familien er innvandrere, muslimer og pakistanere. Utstillingstekstene gir etnisitet prioritet over andre forklaringsmodeller og pakistansk blir en stil på lik linje med arbeiderklassepreg, drakestil og borgerlig hjem i de andre leilighetene. De imaginære individene som befolker de andre leilighetene tilhører mange ulike grupper i samfunnet og deres identiteter er sammensatte. $\AA$ sympatisere med en politisk venstreside er dessuten langt mer selvdefinert og selvvalgt enn å være pakistaner eller innvandrer. I en slik representasjon forsvinner minoritetsindividene som selvstendige aktører som tar individuelle valg og har personlige meninger. De imaginære pakistanske individene blir gjennom tekstene anonyme og fremmede. Sagt med andre ord; "Migrants remain stubbornly migrants" (McShane i Goodnow 2008: 234). Denne etnofikseringen er betegnende for sjangertypen. Goodnow mener at vedvarende utstillingspraksis kan være en av grunnene til at $E t$ pakistansk hjem i Norge er utarbeidet innenfor denne sjangeren (Goodnow 2008: 234).

\section{UTSTILLINGSSJANGER SOM VANT PRAKSIS}

De sammenfallende trekkene mellom En pa- 
38 kistansk leilighet i Norge, tematiske utstillinger og enhancement narratives, kan peke på at praksis innenfor den sistnevnte diskurstypen er en videreføring av tidligere praksiser ved museet.

I kortvarige særutstillinger kan vi gjerne eksperimentere mer i form, men dette er en permanent utstilling og for å være på den sikre siden er vi mer tilbakeholdne med å slippe andre stemmer til. Det har mer usikkerhet knyttet til seg (Pareli 2008).

Sitatet tyder på en slik sammenheng mellom dagens praksis og tidligere praksis. Manglende innflytelse fra pakistanerne i tolkningsprosessen skyldes ikke et bevisst ønske om å unndra dem muligheten til å påvirke egen representasjon, men kan reflektere trofasthet til vante praksiser og usikkerhet knyttet til nye former. Det kan også tyde på at en bestemt utstillingstype er blitt en naturlig del av museet, eller blitt common sense.

\section{UTSTILLINGSSJANGEREN SOM REPRESENTA- SJON}

Museumsutstillinger er nært knyttet til representasjon. Gjennom utstillingene blir objekter og fenomener representasjoner for noe utover seg selv.

En utstilling som skal dekke en hel samfunnsgruppe vil alltid kunne bli kritisert for mangel på representativitet. Det vil lett kunne innvendes at det som er vist ikke er slik som andre i gruppen har det, eller slik noen mener det burde være. Denne type kritikk er umulig å unngå helt. Men den kan imøtegås iallfall et stykke på vei ved å understreke at den valgte løsningen er ett eksempel av mange mulige, og at utstillingen ikke gjør krav på å tale for andre enn seg selv. (NFM hjemmeside).
Argumentasjonen i dette utdraget er som følger: Utstillingen skal representere en hel samfunnsgruppe, museet kan kritiseres for ikke å klare dette og kritikken kan imøtekommes ved å understreke at utstillingen kun representerer seg selv og ikke en hel samfunnsgruppe.

I museumssammenheng kan en snakke om to nivåer for representasjon (Sjöberg-Petarinen 2004: 12). Det første nivået er et resultat av de valg og avgjørelser som fører til at et objekt, en beretning eller en tradisjon blir interessant for et museum. Denne musealiseringsprosessen gjør at museumsgjenstander blir de representasjoner for noe utover seg selv (ibid.). Avgjørelsen om å inkludere den pakistanske leiligheten som representasjon for en innvandrergruppe i Norge er en avgjørelse på dette nivået. Bestemmelsen er basert på kriterier om å inkludere innvandrere.

Det andre nivået for representasjon handler om kunnskapen museet formidler til publikum gjennom utstillingene; formidlingsprosessen. Det er på dette nivået Norsk Folkemuseum mener de kan understreke at utstillingen av den pakistanske leiligheten er ett eksempel av mange mulige. Den pakistanske leiligheten kan altså være en representasjon for innvandrergrupper generelt på det første nivået for representasjon, samtidig som den ikke gjør krav på å opptre på vegne av alle innvandrere eller pakistanere på nivå to. På denne bakgrunnen kan vi også lese følgende sitat fra utstillingstekstene:

Det må understrekes at denne utstillingen ikke prøver å fortelle hvordan alle pakistanere i Norge har det i sine hjem. Det er store forskjeller innbyrdes når det gjelder pakistanske hjem, slik det også er med norske hjem. Her vises ett eksempel (Utstillingstekster).

Utvelgelsesprosessen, eller musealiseringsproses- 
sen, bygger på ulike utvelgelseskriterier. Da museet fikk tilbud om å gjenreise en leilighetsgård fra Oslo, ble det besluttet at en av leilighetene i leiegården skulle vise et innvandrerhjem $(\mathrm{Pa}-$ reli 2004: 51). Pakistanere ble valgt fordi "dette er den mest tallrike utenomeuropeiske innvandrergruppen i hovedstaden og også den som i størst grad setter synlig preg på bybildet” (ibid.). Museet ønsket videre å "illustrere at mange muslimske innvandrere legger vekt på å holde menns og kvinners sfærer skilt" (ibid.: 52). Som en ser her, er det allerede i momentene i utvelgelsesprosessen skapt en sammenheng mellom de tre minoritetsgruppene innvandrere, pakistanere og muslimer, og det er dermed definert en kontekst utstillingen skal plasseres i. Dette kan tyde på at utvelgelseskriteriene har stor innvirkning for hvordan utstillingen blir tolket og formidlet av museet.

I utstillingstekstene og tekstene på hjemmesiden skiller ikke museet tydelig mellom de to ulike nivåene for representasjon. Tekstene henviser til leiligheten som en innvandrerleilighet og indikerer flere steder at leiligheten representerer innvandrere som gruppe. Kriteriene fra musealiseringsprosessen brukes som momenter i formidlingen, og sammenblandingen av de to nivåene for representasjon kan føre til at tekstene blir generaliserende og nyanseringer forsvinner.

Musealiserings- og formidlingsprosessen transformerer fenomener og gjenstander i henhold til kulturelle konvensjoner og praksiser der noen aspekter forsvinner mens andre kommer til. Det er blitt hevdet at nye meninger og verdier som skapes gjennom klassifikasjonssystemer, metoder og praksiser, grunner $\mathrm{i}$ vestlige oppfatninger og vestlige museumskonvensjoner (Kreps 1994: 292). Den strukturelle makten kan således være skjult i konvensjonene og nye minoriteters inntog på museumsarenaen kan være underlagt verdier, meninger og praksiser som favoriserer en vestlig tenkemåte.

\section{MidleRtidige og PERMANENTE UTSTILLINGER}

Sjanger kan også dreie seg om midlertidige og permanente utstillinger. Som nevnt over, indikerer omtales permanente utstillinger $\mathrm{i}$ forbindelse med tematiske utstillinger, mens midlertidige utstillinger knyttes til en kontekstuell utstillingssjanger (Naguib 2004: 9). Permanente utstillinger som sjanger kan indikere et statisk kunnskapssyn $\mathrm{i}$ og med at kunnskapen som produseres på et visst tidspunkt gjøres gjeldende i lang tid. Et statisk kunnskapssyn kan kritiseres fra et mangfoldsståsted for å underkjenne et fleksibelt og prosessuelt kunnskapsbegrep. Et mangfoldssamfunns underliggende prinsipp om at relasjonene mellom samfunn, grupper og individer er i konstant endring, kan komme i konflikt med permanente utstillingsordninger. Det kan tenkes at refleksiv deltakelse for ulike samfunnsgrupper forutsetter fleksible anordninger og at uoverensstemmelsen mellom en statisk utstillingspraksis og et samfunn i kontinuerlig endring, dermed kan innebære en begrenset mulighet for refleksiv deltakelse.

På den andre siden, kan nettopp permanente utstillinger og kjente utstillingsformer virke inkluderende for nye grupper. Norsk Folkemuseum bruker i stor grad hjemmet som utstillingsform. Når En pakistansk leilighet i Norge også utføres med dette uttrykket, blir det satt $\mathrm{i}$ en ramme av forventninger som gjør det lite oppsiktsvekkende. I artikkelen har vi påpekt en del tekstlige momenter som understreker det forskjellskommuniserende. Utstil- 
40 lingen må imidlertid også sees i lys av den felleskommuniserende konteksten leiligheten befinner seg i nettopp i kraft av også å være et hjem i likhet med de fleste andre permanente utstillingene ved Norsk Folkemuseum. Det pakistanske blir dermed ikke noe ekstraordinært, men får den samme uttrykksformen som mange av de andre utstillingene. Hjemmet kan fungere som symbol på tilhørighet og understreke minoriteters tilhørighet til Norge. Konteksten kan slik være en inngangsport til aksept for mangfold. Hjem-konteksten presiserer videre at utstillingen er et utsnitt av virkeligheten og ikke en representasjon som gir seg ut for å gjelde en stor gruppe, til tross for at tekstene kan antyde dette.

Kreps (1994) mener at det nettopp er strukturelle endringer som skal til for at mangfoldsperspektiver skal bli en integrert del av museumsinstitusjonen. For å utfordre konvensjonelle praksiser må en ikke bare endre museenes praksis, men også selve vitenskapen bak museumsinstitusjonen; museologien. Hun etterlyser en gjennomgripende ny, komparativ museologi som markerer at det finnes mange ulike former for museologi (Kreps 1994: 301). En komparativ museologi kan problematisere vår forståelse av hvordan museer utvikles og fungerer i ulike kontekster og hvordan de påvirker dynamikken i kulturell utvikling. Dette kan føre til en demokratisering av museumsinstitusjonen, en jevnere maktfordeling mellom ulike grupper og dermed fordeling mellom flere stemmer. Dess større ideologisk mangfold, dess mindre kan begrensede ideologier behandles som common sense. For å unngå at museologiens språk snakkes av en utvalgt gruppe og dermed opprettholder denne gruppens hegemonisk makt, etterlyses en bredere og mer inklusiv representasjon med mangfoldige stemmer, noe som forutsetter endringer både i utdanningsinstitusjonene og i rekrutteringspraksisene (Kreps 1994: 301).

\section{AVSLUTTENDE BETRAKTNINGER}

Mangfoldsdiskursen innebærer en utvidet forståelse av deltakelse i museumssammenheng, der minoriteters mulighet til innflytelse skal vedrøre ulike nivåer i virksomheten.

Konflikten mellom en gammel og en ny museumsdiskurs kan ha ført museene inn i en identitetskrise (Haukelien 2006: 38). Norsk Folkemuseums tradisjonelle rolle var nært knyttet til ideen om nasjonen som en enhetlig størrelse med klare grenser utad og sterk identitetsskapende betydning innad. Denne oppgaven har fått svekket legitimitet på samme måte som mange andre autoritative fortellinger om nasjonen og fellesskapet bygd på enhet og likhet.

Det mangfoldige museumsfeltet har blitt undersøkt gjennom utstillingen Et pakistansk hjem i Norge, som er et pilotprosjekt i mangfoldssammenheng i Norge. Artikkelen har vist at mangfoldsarbeidet er i gang ved museer i Norge og at mangfoldsarbeidet innebærer en forholdsvis stor omveltning på museumsfeltet. Det handler ikke bare om å gi innpass til nye grupper eller å representere nye stemmer, men også om bakenforliggende strukturer. Gjennom tekstlige analyser har forestillinger og premisser kommet frem i lyset. Først når en ser disse strukturene kan de utfordres og avnormaliseres. Museene har enda en vei å gå om det er et mål å innfri fordringene i mangfoldsdiskursen som kommer fram i offentlige dokumenter.

Når det gjelder deltakelse på de fire ulike nivåene har undersøkelsene for det første vist at en minoritet er blitt en permanent del av museets samlinger og utstillinger og dermed 
en anerkjent del av norsk kulturarv. For det andre viser detaljerte tekstanalyser av utstillingstekster og tekster knyttet til utstillingen på museets hjemmeside, at refleksiv deltakelse er begrenset av bestemte lingvistiske kategoriseringer av begreper som innvandrer, pakistaner og muslim. Undersøkelse av såkalte subjektposisjoner og forestillingen om en ideell leser, gir majoriteten rollen som publikum. Innenfor kategorien majoritetsnorsk finnes nyanseringer og variasjon i smak, mens pakistanere ikke presenteres med et tilsvarende mangfold. Nivå tre, deltakelse som bidrag har museet gjort et grundig forarbeid og hatt et tett samarbeid med den pakistanske informantfamilien, noe som har innebåret nye metoder for museumsarbeid. I institusjonssammenheng har museet utviklet og utprøvd nye metoder for samarbeid med informantgrupper og bidratt til å utvide praksis for utstillingsproduksjon. På strukturelt nivå legger sjangerkonvensjoner føringer for en begrenset deltakerrolle for minoritetene. Bak strukturell deltakelse kan en finne museumskonvensjoner som hevdes å favorisere en vestlig tenkemåte og verdiforståelse. For å utfordre et slikt hegemoni hevdes det at det er behov for en ny komparativ museologi bestående av et mangfold av ulike former for museumsforskning. I lys av de nevnte modellene for kulturelt mangfoldige samfunn, kan en hevde at museunsinstitusjonen politisk og visjonært befinner seg innenfor en salatbollemodellen, mens den i praksis i større grad samsvarer med core+-modellen.

Funnene kan, på grunn av et utpreget tekstfokus, ikke hevdes å gi et helhetlig bilde av formidlingsvirksomheten rundt Et pakistansk hjem i Norge. Likevel kan teoretisk og metodologisk tilnærming være betydningsfulle innspill i en mangfoldsdebatt. Funnene kan sees på som kritiske innspill til den representasjokemuseum har en viktig maktposisjon i et demokratisk samfunn der kritisk dialog og refleksjon har en avgjørende og naturlig plass. Initiativene de har tatt til mangfoldsinkludering og arbeid med utvidelse av praksis og begreper, er vesentlige prosesser i et mangfoldig Norge.

\section{NOTER:}

1. Artikkelen bygger på forfatterens masteroppgave (Hauge 2008).

2. UNESCOs Our creative diversity 1995, ICOM Policy Statement 1997, UNESCOs Universal Declaration on Cultural Diversity 2001, UNESCOs Convention on the Protection and Promotion of Cultural Expressions 2005, Stortingsmelding nummer 22 1999-2000, Stortingsmelding nummer 48 2003-2004, Stortingsmelding nummer $492008-2009$.

\section{LITTERATUR:}

Akman, Haci (1995): Landflyktighet. En etnologisk undersøkelse av vietnamesiske flyktinger $i$ eksil. Bergen: Forlaget Migrasjonslitteratur

Ashworth G.J, Brian Graham og J.E. Tunbridge (2007): Pluralising pasts. Heritage, Identity and Place in Multicultural Societies. London: Pluto Press

Fairclough, Norman (2001): Language and Power. Harlow: Longman

Fairclough, Norman, Guiseppina Cortese og Patrizia Ardizzone (red.) (2007): Discourse and Contemporary Social Change. Bern : Peter Lang

Goodnow, Katherine og Haci Akman (red.) (2008): Scandinavian museums and cultural diversity. New York: Berghahn Books 
42 Goodnow, Katherine og Hanne-Lovise Skartveit (red.) (2010): Changes in museum practice. New media, Refugees and Participation. New York: Berghahn Books

Hauge, Ingeborg (2008): Museum og Mangfold. En kulturvitenskapelig undersøkelse av mangfoldsinkludering ved Norsk Folkemuseum. Masteroppgave i Kulturvitenskap ved UiB.

Haukelien, Heidi (2006): Norsk på nytt. En evaluering av prosjektet Norsk i garr, i dag, i morgen? Bergen: Norsk Kulturråd

Kjeldstadli, Knut (red.) (2003): Norsk Innvandringshistorie. I globaliseringens tid 1940 - 2000. Oslo: Pax Forlag A/S

Kreps, Christina (1994): «The Paradox of Cultural Preservation in Museums» Side 291-306 i The Journal of Arts Management, Law and Society, Vol 23, nr 4

Miegel, Fredrik, og Fredrik Schough (1998): Dikotomier. Vetenskapsteoretiska reflektioner. Lund: Studentlitteratur

Naguib, Saphinaz-Amal (2004): «The Aesthetics of Otherness in Museums of Cultural History.» Side 5-22 i Tidsskrift for kulturforskning, nr. 4

Pareli, Leif (2004): «Et pakistansk hjem på museum.» Side 47-65 i Tidsskrift for kulturforskning. Vol 3, nr. 3

Sjöberg-Petarinen, Solbjørg (2004): Museer ger mening. Friluftsmuseerna Kolosterbacken och Amuri som Representationer. Åbo: Akademis forlag

Tvedt, Terje (1999): «Eksport av normalisme og import av nomalitet. Om den norske samaritan som maktfigur.» Side 116-132 i Normalitet og identitetsmakt $i$ Norge, av Siri Meyer og Thorvald Sirnes (red.). Oslo: Ad Notam Gyldendal

Vergo, Peter (red.) (1989): The New Museology. London: Reaktion books

Winther Jørgensen, Marianne og Louise Phillips (1999): Diskursanalyse som teori og metode. Roskilde: Roskilde Universitetsforlag

\section{ELEKTRONISKE KILDER:}

ICOM Policy Statement. Museums and Cultural Diversity (1997) http://icom.museum/diversity.html

Norsk Folkemuseums (NFM) hjemmeside(oppsøkt mars 2009): http://www.norskfolkemuseum.no/

Statistisk Sentralbyrå. http://www.ssb.no/innvandring/

Stortingsmelding nummer 22 1999-2000. Kjelder til kunnskap og opplevinghttp://www.regjeringen.no/nb/dep/kkd/dok/regpubl/stmeld/199920 00/Stmeld-nr-22-1999-2000-.html?id=192730

Stortingsmelding nummer 482002 - 2003. Kulturpolitikk fram mot 2014http://www.regjeringen.no/Rpub/ STM/20022003/048/PDFS/STM20022003004 8000DDDPDFS.pdf

Stortingsmelding nummer 172005 - 2006. 2008 som markeringsår for kulturelt mangfold http://www.regjeringen.no/Rpub/STM/2005200 6/017/PDFS/STM200520060017000DDDPD FS.pdf

Stortingsmelding nummer 492008 - 2009. Framtidas museum. Forvaltning, forskning, formidling, fornying. http://www.regjeringen.no/pages/2230188/PDFS/STM200820090049000D DDPDFS.pdf

UNESCOs Our Creative Diversity (1995) http://www.unesco.org/culture/policies/ocd/inde x.shtml UNESCOs Universal Declaration on Cultural Diversity (2001) http://www2.ohchr.org/english/law/diversity.htm

UNESCOs Convention on the Protection and Promotion of Cultural Expressions (2005)http://portal.unesco.org/en/ev.phpURL_ID=31038\&URL_DO=DO_TOPIC $\& U$ RL_SECTION=201.html 
INTERVJU:

Pareli, Leif (2008) Intervju om den pakistanske leiligheten $p a ̊$ telefon. Intervjuet av Ingeborg Hauge.

\section{ANNET:}

Utstillingstekster til Et pakistansk hjem i Norge. Norsk Folkemuseum

**Ingeborg Hauge, kulturviter, mastergrad $i$ kulturvitenskap ved universitetet $i$ Bergen

Address: Ekregaten 9, Bergen, Norge

E-mail: ingeborg.hauge@gmail.com

*Haci Akman, ass. Professor i Kulturvitenskap ved universitetet $i$ Bergen

Address: Øysteinsgate 3, Bergen

E-mail:haci.akman@abkr.uib.no 